\title{
Human Capital, Parent Size and the Destination Industry of Spinouts
}

\author{
by \\ Mariko Sakakibara \\ UCLA Anderson School of Management \\ Natarajan Balasubramanian \\ Whitman School of Management, Syracuse University
}

CES 19-30

September, 2019

The research program of the Center for Economic Studies (CES) produces a wide range of economic analyses to improve the statistical programs of the U.S. Census Bureau. Many of these analyses take the form of CES research papers. The papers have not undergone the review accorded Census Bureau publications and no endorsement should be inferred. Any opinions and conclusions expressed herein are those of the author(s) and do not necessarily represent the views of the U.S. Census Bureau. All results have been reviewed to ensure that no confidential information is disclosed. Republication in whole or part must be cleared with the authors.

To obtain information about the series, see www.census.gov/ces or contact Christopher Goetz, Editor, Discussion Papers, U.S. Census Bureau, Center for Economic Studies 5K038E, 4600 Silver Hill Road, Washington, DC 20233, CES.Working.Papers@census.gov. To subscribe to the series, please click here. 


\begin{abstract}
We study how spinout founders' human capital and parent size relate to founders' propensity to stay in the same industry as their parents or to go outside the industry. Individuals with high human capital face a higher performance penalty if they form spinouts outside the parent industry, but they also face greater deterrence from large parents if they stay in that industry. Using matched employer-employee data on spinout founders and their coworkers, we find that individuals with higher human capital are less likely to form spinouts in distant industries than in the parent's industry. Further, we find that as parent size increases, such individuals are less likely to form spinouts in the parent's industry and more likely to form spinouts in distant industries.
\end{abstract}

Keyword: Entrepreneurship, spinout, human capital, competition, industry-specific knowledge

\title{
JEL Classification:
}

\footnotetext{
* This research uses data from the Census Bureau's Longitudinal Employer Household Dynamics Program, which was partially supported by the following National Science Foundation Grants SES-9978093, SES-0339191 and ITR0427889; National Institute on Aging Grant AG018854; and grants from the Alfred P. Sloan Foundation. Any opinions and conclusions expressed herein are those of the authors and do not necessarily represent the views of the U.S. Census Bureau. All results have been reviewed to ensure that no confidential information is disclosed. We would like to thank the Associate Editor Martin Ganco and two anonymous referees for their valuable advice and suggestions. We also thank Rajshree Agarwal, Marvin Lieberman, Sonali Shah, seminar participants at Purdue, Cornell and the University of Michigan, and participants and reviewers at the annual meetings of the Academy of Management, Strategic Management Society, the Census Bureau 2017 Research Data Center Conference, and the Kauffman Entrepreneurship Scholars Conference for their helpful comments. We gratefully acknowledge the financial support of the Kauffman Foundation, the Harold Price Center for Entrepreneurial Studies at UCLA Anderson School of Management, the Academic Senate of the University of California, Los Angeles and the Whitman School of Management at Syracuse University.
} 


\section{Introduction}

New firm formation is an important economic process of particular interest to strategic management scholars. New firms bring new products, technologies, and ideas to the market; displace poorly performing incumbents; and alter patterns of competition in their industries. Our study aims to improve our understanding of this critical process of new firm formation. We focus on spinouts—-new firms founded by employees of established firms — and study the interplay among individual human capital, parent firm ('parent') attributes, and the distance between parent and spinout industries on the formation of spinouts.

Spinouts have received attention from researchers in management, economics, and finance (Agarwal et al. 2004; Gompers, Lerner, and Scharfstein, 2005; Klepper, 2007), partly because many industry studies find that spinouts perform better than other types of new ventures (e.g., Klepper and Sleeper, 2005; Klepper, 2007). This superior performance is often attributed to founders’ ability to exploit their industry-specific human capital they developed at their parents (Agarwal et al., 2004; Chatterji, 2009).

In this line of studies, parents are regarded as sources of knowledge, either technological or organizational, and founders act as the channels that transfer that knowledge from the parents to spinouts. Consistent with this view, studies find that large parents generate more spinouts (Agarwal et al., 2004) and that spinouts of larger parents perform better (Hvide, 2009). However, parents can also deter spinout formation in at least two ways. They may dissuade potential founders from forming spinouts by compensating them well, by providing them better career opportunities within their firm, or by using other means to reduce the attractiveness of the entrepreneurial opportunity. Further, parents can be competitive threats to spinouts and thus influence the formation and performance of spinouts (Walter, Heinrichs, and Walter, 2014; Starr, Balasubramanian, and Sakakibara, 2018). For example, if spinouts are formed in the parents' 
industry (hereafter 'within-industry spinouts' or 'WSOs'), parents are direct competitors to these spinouts. In such cases, parents can engage in competitive tactics that hurt the post-entry performance of the spinout. Furthermore, it is reasonable to expect the magnitude of this deterrence to vary by the level of individual human capital. Firms may be more motivated to retain individuals with higher human capital or to dissuade spinout formation by such individuals since those spinouts may be more harmful to the parent (Starr et al., 2018). This issue of potential deterrence by parents has not received much attention in studies of spinout performance, with the notable exception of Walter et al. (2014), who find from a survey of 144 German spinouts that spinouts suffer negative consequences from perceived parent hostility. ${ }^{1}$

Although spinout studies implicitly emphasize WSOs because of their focus on a specific industry (Agarwal et al., 2004; Franco and Filson, 2006; Chatterji, 2009), potential spinout founders can develop knowledge at their parents that is applicable outside of the parent's industry ('parent industry'). For example, Henry Ford gained knowledge of portable steam engines while working at his family farm and then as a serviceman for Westinghouse, which he then used to start developing gasoline engines and automobiles while he was with the Edison Illuminating Company (Watts, 2009). Zillow (an online real-estate database company) was formed by ex-employees of Microsoft and Expedia (an online travel company that was formed within Microsoft) by utilizing their knowledge of text-based internet services. Examining broader patterns of employee mobility also suggests that individual knowledge may be widely applicable; e.g., Golan, Lane, and McEntarfer (2007) find that approximately half of the people who switch jobs go to different SIC

\footnotetext{
${ }^{1}$ Studies have examined the effect of parent size on new firm formation in general, finding that small firms spawn more new firms than large firms do (e.g., Elfenbein, Hamilton, and Zenger, 2010). This literature argues that potential entrepreneurs sort (by ability or preference) into working for small parents because small firms provide autonomy and tighter pay-for-performance, or working for small firms provides experience that will be useful for entrepreneurship.
} 
two-digit industries. Recognizing that spinouts can be formed outside the parent industry ('out-ofindustry spinouts' or 'OSOs'), some recent studies analyze such spinouts (Eriksson and Kuhn, 2006; Andersson and Klepper, 2013; Agarwal and Shah, 2014; Carnahan et al., 2016).

Although the knowledge gained in one industry may be applicable beyond that industry, prior studies from other literature at the firm level also suggest that the relevance of such knowledge is likely to diminish outside the industry (Helfat and Lieberman, 2002; Carroll et al., 1996). For instance, distance to the destination market has been found to have negative performance implications in international business (e.g., Ghemawat, 2001) and in diversification (e.g., Rumelt, 1974). Similar evidence has been found at the individual level. Neal (1995) and Hyatt and McEntarfer (2012) find that people who switch industries typically earn less in the destination industry. Further, these earning losses appear to be higher for individuals with high human capital, as measured by skill and tenure (Neal, 1995; Dustmann and Meghir, 2005; Nefke, Otto and Weyh, 2016). Within the spinout literature, however, limited attention has been devoted to how the distance between spinouts and the parent industry affects spinout formation and how the level of individual human capital relates to this distance.

Addressing these gaps is important for at least two reasons. First, from a strategy perspective, much like any fundamental discussion of competition in an industry pays particular attention to firms entering from other industries (diversifying firms), it is important to consider new firms that are formed by founders from other industries (e.g., Carroll et al., 1996) and to study what factors affect the formation of such firms. Second, from a policy perspective, we want highly capable entrepreneurs to start new firms where they can best utilize their capabilities. However, if parents can potentially impede entrepreneurial activities in their industry and influence the destination industry of entrepreneurs, then relevant policy measures may be called for. 
The main contribution of our study is to address these critical gaps by studying the interactions among founder human capital, parent firm size, and industry distance in the formation of spinouts. The extant literature includes studies about (i) how the level of human capital affects the formation of WSOs (Campbell et al., 2012; Ganco, 2013) and the performance of WSOs (Chatterji, 2009) and (ii) how the size and other characteristics of parents affect the formation of spinouts (Eriksson and Kuhn, 2006) or WSOs (Agarwal et al., 2004; Franco and Filson, 2006). These studies typically examine separate aspects of how founder human capital, parents, and industry distance affect the formation of spinouts. However, a simultaneous examination of these factors is likely to yield a fuller understanding of spinout formation. After all, the founding decisions of potential founders are affected by how their parents would respond to their actions. In turn, the parents' responses are influenced by their own resources and their perception of the potential loss from the spinouts' formation, which is a function of the founders' human capital and how close the spinouts are in competitive space.

We develop our theoretical arguments in two stages. We begin with WSOs and build on some of the seminal studies in the spinout literature (e.g., Agarwal et al., 2004; Campbell et al., 2012) to develop a baseline hypothesis about the relationship between WSO formation and individual human capital. We then extend to OSOs by incorporating the decreasing relevance of industry-specific knowledge inherited by founders as the distance between the spinout and parent industry increases. We argue that individuals with high human capital are more likely to develop industry-specific human capital and face higher opportunity costs of abandoning their industry expertise. Therefore, we expect individuals with high human capital are less likely to form spinouts in industries that are distant from the parent industry. Finally, we incorporate the deterrent effect of parents through parent size and examine how parent size interacts with individual human capital 
to influence the propensity of those individuals to form WSOs. We focus on two ways in which a parent can deter the formation of a spinout: through dissuading the potential founders by providing incentives to stay at the parent and through posing a potential competitive threat if the spinout is formed. We argue that the deterrent effect is likely to be higher for individuals with high human capital given their greater value to the firm or greater potential competition to the firm should they form a spinout. This effect should also be stronger for larger parents because they have more resources to provide incentives to potential founders or enforce threats. Therefore, we expect that individuals with high human capital who work for large parents are more discouraged from forming spinouts in the parent industry than those who work for small parents; however, this deterrent effect is lower when spinouts are formed in a distant industry because parents will not view the spinouts as competitors. Therefore, we expect that as the size of the parent increases, individuals with higher human capital are more likely to form spinouts in distant industries.

We test our theoretical framework using matched employer-employee data covering 30 U.S. states from 1990 to 2008. Our data comprise 4.2 million observations on individuals who formed spinouts, matched to their coworkers at parent establishments in the quarter in which those individuals leave the parent to form the spinout. By limiting the comparison to spinout founders and their coworkers rather than comparing all founders to all workers, we control for differences across parents. We focus on spinouts formed in manufacturing and information technology (NAICS 31, 32, 33, and 51) to make the analysis computationally tractable and because these industries have been the focus of most prior research on spinouts. We classify spinouts into WSOs, OSOs formed in industries related to the parent industry (OSO-R), and OSOs formed in unrelated industries (OSO-U) depending on how far the spinout industry is from the parent industry.

Consistent with our predictions, we find that the propensity to form WSOs increases with 
human capital, but this positive association decreases when spinouts are in distant industries. Parent size attenuates the positive association between the propensity to form WSOs and human capital but not the association between the propensity to form OSOs and human capital. This strongly suggests that the deterrent effect of large parents is lower for OSOs than for WSOs.

\section{Theory and Hypothesis Development}

We start by establishing a baseline hypothesis that builds upon on prior literature and highlights the role of individual human capital in the formation of WSOs. We then incorporate the role of industry distance and expand our discussion to include OSOs. We finally analyze how the propensity to form a spinout is affected by the parent's size and the distance between the spinout industry and the parent industry. Our overarching argument is that the propensity to form a spinout is influenced by the expected performance of the spinout, which in turn is determined by the relevance of the individual's human capital and the deterrence from the parent. We view these two factors as being influenced by the distance between the spinout destination and the parent industry. The Online Appendix (Section 8) presents a stylized model formalizing some of these elements.

\section{Human capital and formation of within-industry spinouts}

Individuals, including spinout founders, vary widely in their human capital. Human capital is the result of any investment in "activities that influence future real income [of people] through the imbedding of resources in people” (Becker, 1964: 9). For our purposes, such resources could be any individually resident knowledge or skill that is likely to create value for the individual's employer (Campbell et al., 2012). Some relevant individual human capital includes innate ability, problem-solving capabilities, opportunity-identification abilities, managerial knowledge, and networks. Spinout founders inherit knowledge from and develop their human capital at their parents, which improves the survival and post-entry performance of their new firms (Helfat and 
Lieberman, 2002; Agarwal et al., 2004, 2016; Klepper and Sleeper, 2005). Economic theory suggests that human capital should also influence a founder's entry decision since that decision is contingent on the expected post-entry performance of the new firm and the associated returns to the founders (Hamilton, 2000). Not surprisingly, studies have found that founder human capital has a positive effect on post-entry performance (e.g., Phillips, 2002; Campbell et al., 2012). Consistent with this, studies suggest that individuals with high human capital are more likely to form WSOs (Campbell et al., 2012; Ganco, 2013). This is also consistent with the evidence in broader entrepreneurship studies that high-earning individuals are more likely to start new firms (e.g., Astebro, Chen, and Thompson, 2011; Elfenbein et al., 2010). Thus, our first hypothesis, intended to be a baseline hypothesis, is as follows:

Hypothesis 1: Compared with individuals with lower human capital, those with higher human capital are more likely to form spinouts in the parent's industry.

\section{Industry distance, knowledge relevance and formation of out-of-industry spinouts}

While prior literature on spinouts has focused on WSOs, spinouts can be formed anywhere in relation to the parent industry. A majority of employees who switch jobs move to jobs outside their industries (Golan et al., 2007), which suggests that knowledge gained at parents can be applied to contexts beyond the parent industry. Similarly, many types of knowledge inherited by spinout founders (e.g., knowledge about marketing (Chatterji, 2009) or organizational routines and practices (Phillips, 2002)) can be transferred to new firms outside the parent industry. Even technological knowledge can often be applied more broadly. Indeed, this assumption underlies many models of employee startups (e.g., Anton and Yao, 1995; Cassiman and Ueda, 2006).

Though useful, the relevance of inherited knowledge to the performance of the spinout is likely to decrease with distance from the parent industry. This is because a large part of founders' 
knowledge is often acquired in the context of a specific industry, which, though applicable to "nearby" industries, is not very useful in "distant" industries. For instance, while knowledge of organizational routines and practices in law firms (Phillips, 2002) may be beneficial to a new law firm and perhaps to a new professional firm, it is less likely to apply to a new processmanufacturing firm. Neal (1995) offers empirical evidence for this argument. He finds that although pre-displacement tenure in an industry is positively correlated with post-displacement wages for all displaced workers, the correlation is much stronger for industry-stayers than industryswitchers. This indicates that even though workers are able to leverage their knowledge of the old industry in the new industry, such knowledge is less relevant. Further, this negative effect of switching industries persists, albeit to a smaller extent, even after controlling for switching skills (Poletaev and Robinson, 2008). They attribute this to "crystallized skills or knowledge connected to the product...that would be lost if [the worker] switched industries” (p. 413).

This depreciation in the relevance of knowledge is likely to be particularly strong for individuals with high human capital, who are more likely to have industry-specific knowledge than individuals with low human capital. Learning is a function of an individual's existing knowledge base and learning ability, as typically conceptualized in the process of knowledge production (Griliches, 1979). Given the same starting point and industry tenure, individuals with high human capital will have a larger base of industry knowledge and a higher net marginal benefit (i.e., marginal benefit minus marginal cost) of increasing that knowledge base than individuals with low human capital. Switching to a new industry decreases the relevance of old-industry knowledge base to learning in the new industry (though it may be superior to starting from a point of zero knowledge in the new industry). Assuming wages depend on industry knowledge, on average, individuals will switch only if the wages per unit of knowledge is higher in the new industry than 
in the old industry. Further, if individuals with a larger knowledge base in the old industry switch, they will have to forego the higher marginal benefit associated with their larger knowledge base. Hence, such individuals will require a greater than proportionate increase in wages before they switch industries, making them less likely to switch industries than individuals with low human capital. A stylized model of the industry-switching decision based on these arguments is presented in the Online Appendix (Section 7). ${ }^{2}$

In line with this reasoning, Dustmann and Meghir (2005) find that the returns to tenure in an industry, as measured by earnings, are higher for skilled workers than for unskilled workers. Further, Brown, Haltiwanger, and Lane (2006) find that workers in higher-wage, particularly hightech, industries tend to gain by staying within that industry. Similarly, Neal (1995) finds significant wage losses for displaced workers switching to new industries, which are greater for workers with higher human capital (as measured by experience and tenure). In a more recent study, Nefke et al. (2016) examine inter-industry labor flows and find that while nearly three-fourths of workers in cleaning and security cross sector borders, a far lower proportion of workers in higher-skilled occupations such as management (58.4\%), accountancy (58.4\%) and IT jobs (58.5\%) do so. Further, among the latter, those who switch tend to switch to industries closer to their old jobs. This is particularly relevant since many of these occupations are not considered to be industryspecific. Thus, the study's findings strongly suggest that “moving to a radically different industry is less attractive when human capital requirements are higher” (p. 10).

Together, these arguments imply that individuals with high human capital are likely to

\footnotetext{
${ }^{2}$ Briefly, we assume $K_{t+1}=\theta K_{t}^{d \alpha}$ where $K$ is knowledge stock, $\theta$ is human capital, $\alpha<1$ reflects diminishing returns, and $d \leq 1$ is depreciation due to industry distance. When switching industries, individuals compare the marginal benefit of staying in the old industry (and increasing their knowledge stock) with the marginal benefit of switching to the new industry, which has a higher wage per unit of knowledge but a lower relevance of knowledge stock.
} 
suffer a greater loss of knowledge relevance as they move farther from their parent industry. Hence, they have less incentive to form spinouts in industries distant from their parent industry. ${ }^{3}$ Hypothesis 2: Individuals with higher human capital are less likely to form spinouts in industries that are distant from the parent's industry than in the parent's industry.

\section{Deterrent effect of larger parents}

We analyze how parent size affects an individual's propensity to form spinouts and how that effect changes with the individual's level of human capital by focusing on the costs and benefits of forming spinouts. An individual is likely to form a spinout if the expected profit from the spinout exceeds his or her expected earnings from staying at the parent. Examining the formation of a WSO first, there are two ways in which a larger parent may discourage WSO formation to a greater extent than a smaller parent: (a) by providing more resources or compensation to employees (so that their expected earnings from staying increases) and (b) by being a stronger potential competitor and posing a greater competitive threat to the spinout in both input and output markets (so that the expected profit from forming decreases). We call (a) the dissuasive effect, (b) the competitive threat, and the combined effect of (a) and (b) the deterrent effect, and we argue that these effects increase as the parent size increases.

Dissuasive effect. Parents may offer incentives or work environments that dissuade spinout formation (Campbell et al., 2012). Given the cost of replacing productive employees, employers provide incentives to stay by offering higher pay and better work conditions to the workers they want to retain. This effect is likely to be higher for larger firms since such firms typically have

\footnotetext{
${ }^{3}$ Note that our argument is about specialization based on industry specificity of human capital, not specialization based on occupation, a la Lazear (2004). For instance, individuals may build different functional skills (e.g., in marketing and manufacturing) in the same industry if they want to become entrepreneurs.
} 
greater resources and hence can provide more such incentives or offer alternative opportunities (Kacperczyk and Marx, 2016). This will increase individuals' opportunity cost of leaving employment at a larger firm and reduce their propensity to form a spinout. Evidence consistent with this is found in prior studies (e.g., Elfenbein et al., 2010). Additionally, because individuals with high human capital contribute more to the parent, the parent will likely provide more incentives for such individuals to stay (Zenger, 1992).

Competitive threat. A parent may be hostile to the spinout because it may lose critical firmspecific skills and other resources to the spinout (Walter et al., 2014). A parent may also pose a more direct competitive threat to the spinout if the two firms are in the same industry (Klepper and Sleeper, 2005). For instance, a parent can retaliate with lower prices, offer a similar product, or engage in other competitive tactics that reduce the spinout's profits. This direct competitive effect is also likely to be higher for individuals with high human capital and for employees at larger parents. Individuals with high human capital are likely to have better ideas that have the potential to cause more damage to a parent's performance (Starr et al., 2018). Hence, a parent may respond aggressively to such spinouts. Moreover, larger parents are likely to have the resources to respond aggressively. Expecting such a potential competitive threat, individuals with high human capital might be discouraged from forming WSOs when they have large parents.

Therefore, the combined deterrent effect discourages individuals with high human capital at large parents from forming WSOs. This implies the following:

Hypothesis 3a: As the size of the parent increases, individuals with higher human capital are less likely to form spinouts in the parent's industry.

\section{Industry distance and the deterrent effect of larger parents}

In distant industries, both the dissuasive effect and the competitive threat from the parent decrease. 
Focusing on the competitive threat, a vast majority of firms compete in narrow industries and often in only one (e.g., Jarmin, Klimek, and Miranda (2004) find that 94\% of firms in the U.S. retail sector are single-industry firms, and the average number of 4-digit SIC industries for multi-unit firms is only approximately 1.3). Compared with this, individual knowledge about technology and industry can be applied more broadly, as seen by the significant movement of workers across 2digit SIC industries (Golan et al., 2007). Hence, parents are less likely to be concerned about competition from spinouts in industries that do not directly compete with them, and their incentive to impose a competitive threat on spinouts declines. Consistent with this rationale, Walter et al. (2014) find that product differentiation reduces the impact of parent hostility on spinout performance, and Clarysse et al. (2011: 1420) find that corporate spinouts grow most if "they start with a specific narrow-focused technology sufficiently distinct from the technical knowledge base of the parent.” Similarly, Starr et al. (2018) focus on noncompete agreements as one specific threat that a parent can impose, and they present a model where the probability of noncompete enforcement decreases as the distance between the spinout and the parent increases.

Turning to the dissuasive effect, parents are less likely to make offers to dissuade employees who wish to found OSOs than those who want to form WSOs. Because of greater distance from the parent, the profit decline that parents face due to a new OSO is likely to be lower than that from a new WSO. Hence, for any given level of employee human capital, the parent has a lower incentive to dissuade employees from forming OSOs. ${ }^{4}$ Thus, Hypothesis 3b: As the size of the parent increases, individuals with higher human capital are more likely to form spinouts in industries distant from the parent's industry.

\section{Data and Empirics}

\footnotetext{
${ }^{4}$ A mathematical formalization of this argument is provided in Section 8 of the Online Appendix.
} 
The primary data for the study come from the "Longitudinal Employer Household Dynamics" (LEHD), a matched employer-employee data set of the U.S. Census Bureau. It provides employment history and wages for all employees in 30 states and quarterly information on employment and payroll for all establishments in those states. Our study is based on 30 states (AR, CA, CO, FL, GA, HI, IA, ID, IL, IN, LA, MD, ME, MT, NC, NJ, NM, NV, OK, OR, RI, SC, TN, TX, UT, VA, VT, WA, WI, and WV). The first year the data are available for at least three states (the minimum required for public disclosure of results) is 1991, and the last year is 2008.

\section{Identification of spinouts}

We divide spinouts into WSOs, related OSOs or OSO-Rs (those at a close "distance" to the parent industry), and unrelated OSOs or OSO-Us (those at a larger distance). Compared with a continuous measure of industry distance, this classification, particularly of OSOs, makes it easier to interpret our results and allows for nonlinearity in the effects of industry distance.

Because the LEHD does not directly identify spinouts, we use employee-movement data from the LEHD to identify them. Our approach follows that of Starr et al. (2018), which draws on Benedetto et al. (2005) in identifying various firm events from these data. Broadly, the approach uses knowledge inheritance from the parent through employee mobility and the relative importance of that knowledge to a new firm to identify spinouts. Thus, conceptually, this approach is similar to that of Andersson and Klepper (2013), who define spinouts as new firms with a majority of founders from the same parent. We begin by identifying "founding clusters" of one to 20 employees moving from one establishment ('the predecessor' or 'the parent') to a new firm ('the successor') within the same state during a one-year period (there are very few interstate clusters). From these clusters, we exclude clusters where the predecessor is too small relative to the cluster size (specifically, we exclude clusters with more than 50 percent of employment at the 
predecessor). This ensures that simple identifier changes do not result in classification as a spinout (Benedetto et al., 2005).

We also exclude clusters where the successor is too large relative to the cluster size (specifically, we exclude clusters with less than 75 percent of employment at the successor). By choosing this cut-off, which is similar to the cut-off used by Benedetto et al. (2005) for these same data (80\%), we attribute importance to the human capital of the founders and the role of the parent, both inherent aspects of spinouts and our focus of attention. Importantly, this rule implies that the founding cluster likely accounts for a majority of the knowledge that resides in individuals at the spinout. Without such a rule, almost every new firm would be a spinout since most individuals are employees at another firm before joining new firms.

Broadly, then, these clusters represent groups of employees moving from an existing firm to a new firm. Employees in this cluster are classified as new firm founders. Since the LEHD is a state-level dataset, we use a national-level dataset (Longitudinal Business Database, or LBD) to exclude firms that appear to be new in a state but belong to a multi-state firm.

We identify WSOs as spinouts that have the same four-digit NAICS code as their parent. Those that have a different code are classified as OSOs. We then classify OSOs into two typesrelated (OSO-R) and unrelated (OSO-U)—based on the distance between the industry of the parent and the industry of the spinout. This is based on a dissimilarity measure computed using the universe of establishments (in LBD) for 2002 and the baseline NAICS 2002 4-digit industry definition. In particular, the distance from industry A to industry B is computed as the negative (log) ratio of the number of firms that had establishments in both industries to the total number of firms in either of these industries. If there are no firms with establishments in both industries, which occurs in a small proportion of instances in our data, we set the distance to be the maximum 
available distance based on other industry pairs. OSOs with a distance less than the median distance are classified as OSO-R, and those with a larger distance are classified as OSO-U (results using alternative cutoffs are consistent). WSOs are uniformly assigned a zero distance. Thus, at the end, we have three types of spinouts: WSOs (24\%), OSO-Rs (38\%) and OSO-Us (38\%).

To create our sample, we append to the list of spinout founders for each spinout all their coworkers in the quarter they left the parent to form the spinout. If there are more than 100 coworkers, we choose a random sample of 100 coworkers for our analysis, along with the appropriate sampling weight. ${ }^{5}$ This results in a matched sample of founders and their coworkers at the time of the founders' leaving the parent, which allows us to examine the propensity to form different types of spinouts after controlling for various effects of the parents. ${ }^{6,7}$ Finally, because most prior studies of spinouts are in the technology and manufacturing sectors, and to keep the computational requirements manageable, we limit our analyses to spinouts formed in manufacturing and information (NAICS 31, 32, 33, and 51) industries. We do not place any restrictions on parent industry.

In the end, we have approximately 83,000 spinouts and 183,000 founders. Corresponding to these founders, we have 4 million coworkers at their parents. These 4 million coworkers are drawn from approximately 118 million coworkers at those parents. Thus, on average, each

\footnotetext{
${ }^{5}$ There were a few instances of parent-year-quarters with multiple types of spinouts, typically with very large parents. In these cases, we randomly assign a separate group of 100 coworkers to each set of founders and accordingly adjust our sampling weights downward.

${ }^{6}$ This sampling strategy follows the logic of a conditional logit model that includes parent-time fixed effects. Such a model will drop all parent-time observations that do not generate any spinouts. This is because the lack of within-group variation in our variable of interest (founder vs. coworker) among such parents implies that they do not contribute information to the estimation.

${ }^{7}$ An alternative approach is to draw a random sample of workers from all firms, not just firms that spawn spinouts. However, our interest is in comparing founders and coworkers exposed to a similar parent environment. Hence, we adopt the current approach over the alternative.
} 
coworker in the sample represents approximately 29 coworkers from the population of coworkers in our data. Descriptive statistics are provided in Table 1. Throughout, all numbers are rounded to meet U.S. Census Bureau disclosure requirements.

— Insert Table 1 Here —

\section{Propensity to form spinouts}

First, we study how the propensity to form spinouts varies by human capital and spinout type. We use human capital deciles (as measured by earnings) in a semiparametric specification. In contrast to linear or quadratic specifications, which impose a predetermined pattern of correlation on the data, this approach allows the coefficients on human capital to vary by decile and thus allows us to paint a richer picture of the role of human capital and to uncover any nonlinearities. We use two specifications to examine propensity. The first is a baseline regression of the following form:

$F_{i k p t}=\sum_{k=1}^{k=10} \alpha_{k} H Q_{i k}+\sum_{k=1}^{k=10} \beta_{k} D_{O S O R} H Q_{i k}+\sum_{k=1}^{k=10} \gamma_{k} D_{O S O U} H Q_{i k}+Z_{i[t]}+\omega_{p t}+\epsilon_{i k p t}$

$F_{i k p t}$ is a binary variable equal to 1 if individual $i$ in human capital decile $k$ belonging to parent $p$ at time $t$ (year-quarter) founded a spinout, and 0 if the individual did not found a spinout. $H Q_{i k}$ denotes the human capital decile of an individual constructed based on the (log) individual's real earnings (in 2008 dollars) in the quarter that he or she left the parent to form the spinout. DOSOR is a dummy variable equal to 1 for the spinout founder and the matched coworkers if the spinout is an OSO-R and 0 otherwise. We define DOSOU analogously for OSO-Us. $\mathbf{Z}$ is a set of time-varying and time-invariant individual-level controls discussed below, and $\omega_{p t}$ are joint parent-year-quarter fixed effects. The human capital deciles are based on the full distribution of earnings across all individuals in the sample. In addition, we allow the intercept and controls to vary by type of spinout. Included in $\mathbf{Z}$ are the individual's (log) experience in the industry of the parent, the (log) experience at the parent, the (log) number of industries the individual has worked in, the (log) 
experience in the spinout industry, the (log) age, the (log) years of education as imputed by the U.S. Census Bureau, a dummy indicating whether the founder is an alien in the U.S., and an indicator of the founder's gender. All these controls except alien and gender are measured in the year-quarter that the founder leaves the parent to form the spinout. Due to Census Bureau disclosure restrictions, we do not present coefficients on alien and gender. Throughout, we cluster standard errors at the parent level to allow for arbitrary correlation of errors within a parent.

Our main coefficients of interest are $\alpha_{k}, \beta_{k}$, and $\gamma_{k}$. We set the lowest decile as the baseline omitted category, and hence, we have nine coefficients in each set corresponding to the other nine deciles. Broadly, $\alpha_{k}$ measures the average propensity of individuals in human capital decile $k$ to form WSOs relative to those in the lowest decile after controlling for individual characteristics and time-varying parent characteristics. We focus on relative propensities rather on absolute propensities, since the latter is a function of the absolute number of ideas for each type of spinout (e.g., there may be many more OSO-U ideas than OSO-R ideas simply because there are many more destination industries) and is unknown. $\beta_{k}$ and $\gamma_{k}$ are quasi difference-in-difference coefficients that measure propensities to form OSOs relative to WSOs and thus reflect the distance effect after controlling for any factors common to the formation of OSOs and WSOs. In particular, $\beta_{k}$ denotes the difference between (i) the average propensity of individuals in human capital decile $k$ to form OSO-Rs relative to those in the lowest decile and (ii) the average propensity of individuals in human capital decile $k$ to form WSOs relative to those in the lowest decile. Analogously, $\gamma_{k}$ refers to the relative propensities to form OSO-Us.

We choose Equation (1) over an alternative multinomial logit (or conditional logit) specification with four individual types (WSO founder, OSO-R founder, OSO-U founder and nonfounder) as the dependent variable because the logit specifications are computationally infeasible 
except for the simplest specification without any fixed effects. Such a specification without any fixed effects would raise many critical issues of unobserved differences across parents driving the results. Hence, we adopt a linear probability model as our main specification and present a simpler multinomial logit specification as a robustness check. Importantly, Equation (1) without fixed effects is identical to estimating three different linear probability models for each spinout type (e.g., whether to found a WSO or not) and comparing coefficients across these models. With fixed effects, Equation (1) is slightly preferable to estimating three different linear probability models since it incorporates information on all three types of spinouts in the estimation. For details, refer Online Appendix (Section 2).

Focusing on the parent-time fixed effects in Equation (1), it is well known that parent characteristics influence the propensity of employees to form spinouts. For instance, a parent may be very entrepreneurially oriented, which will make it more likely for employees at that parent to form spinouts. Other factors, such as the innovativeness of the parent, its performance, and perhaps even something specific to the parent's market conditions, may influence the propensity of employees to form spinouts. There are also temporal variations in spinout formation (e.g., firm entry declines during recessions). By including parent-time fixed effects, we mitigate the confounding influence of these factors.

To test our hypotheses on the role of industry distance and parent size, we modify Equation (1) by interacting the human capital terms with parent size as follows:

$$
\begin{aligned}
& F_{i k p t}=\sum_{k=1}^{k=10} \alpha^{\prime}{ }_{k} H Q_{i k}+\sum_{k=1}^{k=10} \beta^{\prime}{ }_{k} D_{O S O R} H Q_{i k}+\sum_{k=1}^{k=10} \gamma^{\prime}{ }_{k} D_{O S O U} H Q_{i k}+\sum_{k=1}^{k=10} a_{k} S_{p t} H Q_{i k}+ \\
& \sum_{k=1}^{k=10} b_{k} D_{O S O R} S_{p t} H Q_{i k}+\sum_{k=1}^{k=10} c_{k} D_{O S O U} S_{p t} H Q_{i k}+Z_{i[t]}+\omega_{p t}+\epsilon_{i k p t}
\end{aligned}
$$

where $S_{p t}$ is the size of parent $p$ at time $t$, measured as the (log) number of employees at the parent establishment. Here, $\alpha^{\prime}{ }_{k}$ measures if individuals with higher human capital are more likely to form 
WSOs than those with lower human capital (Hypothesis 1).

To test Hypothesis 2, we compare the propensity of individuals to form a WSO relative to the propensity of individuals to form an OSO, and evaluate how this propensity difference changes with individual human capital. This is measured by the quasi difference-in-difference coefficients, $\beta^{\prime}{ }_{k}$ and $\gamma^{\prime}{ }_{k}$. To test Hypotheses 3a and 3b, we evaluate how the relationship between the propensity to form a WSO or an OSO and human capital changes with parent size. This is achieved through the coefficients $a_{k}, b_{k}$, and $c_{k}$, which reflect what happens to the various propensities as parent size increases. Specifically, if $a_{k}$ is negative, it indicates that parent size reduces the propensity of individuals in decile $k$ (relative to those in the lowest decile) to form spinouts.

\section{Earnings as a measure of individual human capital}

We now briefly discuss the use of earnings as our measure of human capital. Individual earnings, either directly or as wage residuals, have been extensively used as a measure of human capital in both the strategic management and economics literature (e.g., Campbell et al., 2012; Carnahan, Agarwal, and Campbell, 2012; Neal, 1995) and are the most commonly used measure of individual human capital in large-data studies (e.g., Hamilton, 2000). Furthermore, studies such as Abowd, Kramarz, and Margolis (1999) find that person-specific effects are the most important determinant of earnings, suggesting that earnings are a good proxy for individual human capital. The other important component of earnings relates to employer effects, which we eliminate by including parent-year-quarter fixed effects in our specifications. We also include several individual-level variables, such as age, gender, and alien status, all of which may influence wages but not reflect human capital. Thus, our specification uses differences in earnings across individuals after controlling for these various other drivers of earnings as a proxy for differences in their human capital, and it is conceptually very similar to the wage residual used in Carnahan et al. (2012) to 
identify high and low performers. A potential concern is that earnings is a reflection of wealth and that our results are primarily driven by wealth constraints rather than human capital. However, it is not clear why pure wealth constraints may affect WSOs and OSOs differently.

\section{Results and Their Economic Significance}

Focusing on simple cross-tabulations, Table 2 shows the relative frequency of founders by spinout type and human capital, as measured by prior earnings decile. Panel A shows the distribution of founder human capital for each type of spinout. Overall, founders with medium and high levels of human capital comprise the majority of all WSO and OSO-R founders, with OSO-R founders dominating at the highest deciles. In contrast, OSO-U founders tend to be predominantly in the lower human capital deciles. Panel B presents the share of each type of spinout for each level of human capital. It shows that the share of WSOs increases with the level of human capital from $25 \%$ in the first decile to approximately $36 \%$ in the fifth decile and then declines slowly to $31 \%$ in the highest decile. Among OSOs, the share of OSO-Rs relative to OSO-Us increases monotonically as human capital increases; indeed, the share of OSO-Rs is monotonically increasing, while that of OSO-Us is monotonically decreasing. These patterns are broadly consistent with our hypotheses.

Turning to the regression results, Table 3 presents the results of estimating Equation (1). Note that the lowest decile is the omitted category, and hence, these coefficients indicate the propensity of individuals in a certain decile to form spinouts relative to individuals in the lowest decile. It is clear from the table that the propensity to form WSOs (Column WSO) increases with human capital up to the seventh decile and then declines slowly. Compared with individuals in the second decile, the probabilities of those in the seventh and last deciles forming a WSO are approximately 0.0046 and 0.0032 higher, respectively. These differences are economically 
significant compared with the weighted average propensity to form WSOs (0.0066).

The other two columns in Table 3 present the coefficients on the interaction of OSO-R and OSO-U with each of the human capital deciles. From Hypothesis 2, we expect that individuals with higher human capital are less likely to form OSO-Rs or OSO-Us. In line with this, we find that relative to WSOs, the propensity to form OSO-Rs has a broad declining trend, consistent with a higher distance penalty for individuals with higher human capital. The coefficients on OSO-U have a similar pattern as the OSO-R but are more negative. Figure $1 \mathrm{~b}$ plots the difference in the coefficients between the two OSO-human capital interaction terms and associated 95\% confidence intervals. It shows that the difference between the propensity to form OSO-Rs relative to OSO-Us increases with the level of human capital, consistent with individuals with higher human capital being able to utilize their knowledge in related industries.

The overall relations between human capital and the propensity to form different types of spinouts are presented in Figure 1a. The figure plots the coefficients on the human capital deciles from Equation (1) for WSOs as well as the sum of the direct WSO terms and the OSO-R/OSO-U interaction terms. The pattern for WSOs is very different from that of the OSO-Rs. In particular, unlike the pattern for WSOs, we do not observe a decline in the propensity to form OSO-Rs among individuals with higher human capital. Rather, human capital and the propensity to form OSO-Rs are positively correlated throughout, with the difference between the second and last deciles being approximately $53 \%$ of the weighted average propensity to form OSO-Rs. Finally, in contrast to both WSOs and OSO-Rs, there is no discernible relation between human capital and the propensity to form OSO-Us. This strongly suggests that individual human capital plays a much larger role in WSO and OSO-R founding decisions than in OSO-U founding decisions. This is consistent with our arguments that individuals with high human capital tend to have more industry-specific 
knowledge, which they apply to their spinouts. Furthermore, the "flatter" profile with respect to human capital for the propensity to form OSOs (relative to WSOs, which has a peak in the middle) is consistent with that of Carnahan et al. (2016), who find that the performance of startups formed by industry outsiders has a higher variance than those formed by insiders.

Our basic control variables are generally in line with expectations. Consistent with being useful for WSOs, parent industry experience is associated with a higher propensity to form WSOs and a lower propensity to form OSOs relative to WSOs. Parent experience is positively associated with the propensity to form spinouts in general. The length of education is positively associated with the propensity to form WSOs. There is no additional effect on OSO-Rs, while there is a negative effect on the propensity to form OSO-Us. Since education is also a rough proxy for general human capital, these results are consistent with WSOs and OSO-Rs being more human capital intensive. The number of industries an individual has worked in, not unexpectedly, has a negative effect on the propensity to form WSOs but a positive effect on the propensity to form OSOs, both relative to WSOs and in absolute terms. Experience in the spinout industry is negatively correlated with the propensity to form WSOs and, relative to that, positively correlated with the propensity to form OSOs.

— Insert Tables 2 through 4 and Figure 1 about Here -

Table 4 presents the results of estimating Equation (2), which incorporates parent size. For brevity, the coefficients on the controls, which are similar to those in the previous table, are not presented. Focusing on the WSO-related direct terms first (Column WSO), the coefficients increase with the level of human capital up to the eighth decile and then declines, but the decline is much smaller than what is seen in Figure 1a. This supports our baseline Hypothesis 1 which predicts that the propensity to form WSOs increases with human capital, and is consistent with 
what one would expect in smaller parents. Consistent with Hypothesis 2 and similar to Table 3, we find that relative to WSOs, the propensity to form OSO-Rs or OSO-Us is lower for individuals with higher human capital.

The coefficients on the interaction of parent size with human capital deciles broadly decrease with human capital. This indicates that as the size of the parent increases, individuals with higher human capital are less likely to form WSOs (Hypothesis 3a). Another interesting result is that although the magnitude of the coefficients on parent size-human capital interactions is much higher for individuals with high human capital, it flattens out or even weakly decreases at the highest deciles. For instance, the coefficient on the fifth decile is nearly three times that on the third decile, but the coefficient on the tenth decile is only approximately $20 \%$ higher than that on the fifth decile. This less-than-proportionate effect at the higher deciles suggests that a greater proportion of individuals with the highest human capital have expected returns high enough to overcome the parent deterrent effect so that they form WSOs at about the same rate as individuals with medium levels of human capital.

Turning to the differential effect of parent size by the industry distance of spinouts, from Hypothesis 3b, we expect that as parent size increases, individuals with higher human capital are more likely to form spinouts in industries distant from the parent industry. This is indeed what we find. The coefficients on the triple interactions with OSO-R in Table 4 (Column OSO-R) show that relative to WSOs, the propensity to form OSO-Rs is increasing in human capital as parent size increases. The corresponding triple interactions for OSO-U are larger. Together, these findings strongly suggest that the deterrent effect of large parents on individuals with high human capital declines as they move farther from the parent industry.

\section{Robustness checks}


We perform a number of checks to assess the robustness of our results. We discuss them briefly here and present the numerical results in the Online Appendix.

\section{Alternative specifications and measures}

First, we repeat our two baseline specifications without using weights. The results are similar to the weighted regressions (Figures A1.1a-A1.1c in the Online Appendix), with changes one would expect if larger firms were underweighted. Classifying spinouts into two types (WSOs and OSOs) instead of three does not make any difference in our inferences (Tables A1.1a-A1.1b). Using alternative measures of industry experience (Tables A1.2a-A1.3b) results in similar inferences. Dropping individual experience variables yields similar results. Similarly, using a continuous measure of distance rather than the trichotomous classification does not make any major changes to our key inferences (Tables A1.4a-A1.4b). Using the number of establishments as a measure of parent size yields qualitatively similar results (Tables A1.5a-A1.5b). We also include additional interaction variables between human capital deciles and average parent wage as controls to our baseline specifications (Tables A1.6a-A1.6b). This addresses the concern that if "middle earners" are disproportionately present in high-paying firms and such firms do not retain these individuals, we may see a high propensity to be a founder by such middle earners. However, our results do not support that thesis. We also estimate using quantiles based on earnings within the parent and find our baseline results to be similar (results not presented due to disclosure restrictions). Finally, parent size may simply reflect industry-level entry barriers that reduce spinout formation. To rule this out, we added interactions of human capital deciles with industry capital intensity and R\&D intensity and re-estimated our results. The results remain robust (Table A1.8).

Further, we estimate a simple multinomial logit specification to rule out potential issues with the use of a linear probability specification. As discussed earlier, only the simplest 
specification without any fixed effects is computationally feasible. Table A2.1 in the Online Appendix presents the estimates. The basic pattern of the results is similar to our baseline results. First, the probability of founding WSOs increases in human capital and then decreases beyond the seventh decile. Second, the propensity to form OSO-Rs or OSO-Us for any given human capital decile is considerably lower than the propensity to form WSOs. Thus, it does not appear that our key inferences are susceptible to a change in the type of specification.

\section{Occupational differences in industry-specificity}

Our data do not include any information regarding the occupation of individuals. It is possible that individuals with higher human capital are in occupations with more general skills (e.g., accountants and lawyers). Hence, occupation differences rather than the industry specificity of human capital may account for the decline in the propensity to be a WSO founder for individuals with high human capital.

Although we cannot completely rule this possibility out, we examined aggregate data from the Occupational Employment Statistics to check whether occupations map to earnings deciles in a way that drives our results. (We thank an anonymous referee for suggesting this analysis.) We did not find any such patterns. Section 3 of the Online Appendix provides details. Further, within our sample, we find that the number of industries a person has worked in is strongly negatively related to the person's earnings (Table A3.1 in the Online Appendix). This is consistent with the thesis that individuals with higher human capital tend to have industry-specific human capital.

\section{Definition of founder}

Since the data do not explicitly identify founders, we assume that all individuals in a "founding cluster" that moved from a parent to a spinout during the first year of the spinout are "founders." To the extent that non-founders differ from founders (in that they may not be subject to the same 
deterrent effects), this adds noise and will likely attenuate the results (since our founding cluster may include joiners as defined in Roach and Sauermann, 2015). To provide further confidence in our results, we re-estimated our results after re-defining founders to be the highest-earning individual in the founding cluster. Our results were similar to the baseline results. We also reestimated our results after restricting our sample to spinouts where the founding cluster joined the spinout in the first quarter of the spinout's existence. These results were virtually identical to the baseline results. We briefly discuss this in Section 4 of the Online Appendix.

\section{Classification of spinouts}

One of the rules used to classify spinouts is that the size of the employee cluster moving to a new firm comprises at least 75 percent of employment at the new firm. We performed a series of tests to address the potential concern that this rule spuriously induces the observed results, including an analysis of the spinouts' subsequent hires. The results of these tests, presented in Section 5 of the Online Appendix, suggest that the cut-off rule is unlikely to be the primary driver of our results.

\section{Discussion and Conclusion}

\section{Role of industry distance}

Our results highlight the economic importance of where in the entrepreneurial process. Many studies have examined why founders choose to found new firms, but detailed studies of entrepreneurial destination are, to our knowledge, rare (Carnahan et al., 2016, being one). Indeed, although most studies of spinouts examine new firms formed in the same industry as their parents, WSOs make up only $24 \%$ of spinouts in our sample; the majority of spinouts in our sample are not in their parent industries. Thus, by incorporating both WSOs and OSOs, our study extends the literature on how the level of human capital affects the formation and performance of spinouts (e.g., Chatterji, 2009; Campbell et al., 2012; Ganco, 2013), which has largely focused on WSOs, 
and studies such as Sapienza et al. (2004) and Clarysse et al. (2011), which examine how knowledge relatedness between spinouts and parents affects the performance of spinouts. In this regard, our results complement those of Carnahan et al. (2016), who examine the differences in the variance of performance between startups formed by individuals in the same industry and startups formed by founders from related industries.

More specifically, our results strongly suggest that how far from the parent industry entrepreneurs go is affected by both their human capital and parent size. Focusing on the distancehuman capital relation first, the OSO-R and OSO-U interaction terms in Table 3 show a broad decreasing trend with human capital. Since these are relative to WSOs, they are consistent with our arguments that the applicability of founder human capital diminishes with distance from the parent industry, especially for individuals with high human capital. Similar effects of industry distance on where firms enter are found in the international business and corporate diversification literature, but to our knowledge, this is the first study to show such an effect in entrepreneurship.

Our theoretical arguments and results regarding the role of industry distance also broadly parallel and are consistent with arguments in the literature that entrepreneurs with high and low human capital have different motives and orientations in entering entrepreneurship. Specifically, individuals with low ability might become entrepreneurs out of necessity because they face low wages and therefore have a low opportunity cost of starting a new firm (or they might also perceive their current job to be a poor fit with their ability). On the other hand, workers with high ability may start their business out of opportunity: they recognize business ideas whose potential return exceeds their current wage level (Poschke, 2013). Our results strongly suggest that these two groups of entrepreneurs also differ considerably in where they are likely to form a new firm.

\section{The deterrent effect of large parents}


The other major contribution of our results is that they shed light on the deterrent effect of large parents. We find that this deterrence is particularly high for WSOs formed by individuals with high human capital. This can be seen in Figure 1c, which presents the predicted propensity (relative to individuals in the first decile) for the three spinout types at two parent sizes. The propensity to form WSOs increases monotonically with human capital in a smaller parent but drops sharply with human capital in a larger parent. The effect is much less pronounced for OSOs. Thus, these findings extend those of Elfenbein et al. (2010) and provide a fuller understanding of the deterrent effect of large parents by distinguishing among different types of spinouts and individual human capital. We also take a parent's perspective, which is complementary to an individual's perspective taken by previous studies (e.g., potential entrepreneurs choose to work for small parents).

Prior studies have generally focused on the knowledge and resource benefits of being at large firms or on the competitive effect of the spinout on the parent (e.g., Eriksson and Kuhn, 2006; Agarwal et al., 2004; Franco and Filson, 2006; Walter et al., 2014; Campbell et al., 2012). While founders of a spinout do derive knowledge and resource benefits from large parents, these parents can also deter the formation of the spinout, especially if the spinout is a WSO.

Although our data do not allow us to disentangle the relative roles of dissuasion and competition in driving the deterrence, our results and other related tests suggest a role for both of these mechanisms. In line with larger parents dissuading individuals with high human capital, we see that individuals at larger parents are less likely to form spinouts. This dissuasive effect exists for both OSO-Us and OSO-Rs, both of which are unlikely to be affected by parent competition. Table A1.7 in the Online Appendix presents Table 4 with OSO-U as the omitted category. The coefficient on parent size is still negative for individuals with higher human capital, suggesting the existence of a small dissuasive effect for OSO-U founders. 
The competitive threat of parents is suggested in the stronger effect of parent size on WSOs, consistent with parents being potential competitors to such spinouts. As another test, we analyzed whether parent size reflects a competitive threat to spinout founders through its market power. We included the interaction of parent's industry logged employment share (as a proxy for its market share) with spinout type and human capital deciles (in addition to parent size interaction terms) in Equation (2). Focusing on terms pertaining to WSOs (Table A6.1 in the Online Appendix), we find that interactions of log parent employment share and human capital deciles are small and statistically insignificant compared to coefficients on parent size. Thus, parent market share does not appear to have a large role in explaining the results of parent size.

We then examined one institutional factor that allows parents to impose a threat on spinout founders: enforceability of noncompete agreements. Where enforceable, such agreements allow parent firms to take legal action against spinout founders who start a competing firm (that is, a WSO). Since the enforceability of these agreements differs across U.S. states (e.g., California does not allow such agreements), the ability of parents to impose such a threat also varies across states. We assessed and confirmed that the interaction of parent size and two measures of noncompete enforceability is negative and increasing in human capital for WSO formation (Tables A6.2 and A6.3 in the Online Appendix). This suggests that the competitive effect of large parents (on WSO formation) is indeed greater in states with higher enforceability, which is consistent with a greater ability of larger parents in these states to impose a threat on spinout founders. We also tested and ruled out the possibility that parent size reflects diversification (Table A6.4). We further tested whether parent size increases the propensity of founders to form spinouts in supplier industries to the parents (as one might expect if parent firms were a competitive threat to spinout founders). We created a new category of supplier industry spinouts and found the results of this category (Tables 
A6.4 and A6.5 in the Online Appendix) to be similar to those of OSO-Rs (and thus consistent with a competitive threat). Together, these results support a competitive threat based explanation.

\section{Performance implications}

Since the propensity to form a spinout is influenced by the expected performance of the spinout, there is a natural correspondence between expected performance and observed performance. To test the effects of factors that influence formation on observed performance, we broadly follow the same approach used for formation analysis. We analyze performance at the firm level. Due to the smaller sample size, using human capital deciles and joint parent-year-quarter fixed effects is infeasible. Hence, we use a specification similar to Equation (2) with spinout performance (as measured by employment at ages 0 and 3) as the dependent variable regressed on spinout type and a full set of its interactions with parent size and founder human capital (the earnings of the highestearning founder) along with industry-year fixed effects.

\section{— Insert Table 5 Here —}

Table 5 presents the results. Consistent with the formation results and prior studies, the results show a negative coefficient on the OSO-R dummy and an even larger negative coefficient on OSO-U (Cols. 1 and 4). When the full set of interactions are included (Cols. 3 and 6), the coefficient on founder human capital is always strongly positive, and the interaction of founder human capital and spinout type is negative for the OSOs, consistent with a negative effect of industry distance on OSOs for individuals with high human capital. Additionally, consistent with a deterrent effect of large parents on WSOs formed by individuals with high human capital, the coefficient on the interaction of founder human capital and parent size is negative. The three-way interaction terms are positive for both OSO-Rs and OSO-Us, consistent with a smaller deterrence effect from (large) parents for individuals with high human capital who form OSOs. A robustness 
check using spinouts from all industries is presented in Table A1.9 of the Online Appendix.

These results shed light on another understudied topic - the performance difference between WSOs and OSOs. Exceptions include Dahl and Sorenson (2014), who argue that OSO founders have different motivations to form new firms compared with WSO founders and find that the difference in motivation explains some of the performance differences between WSOs and OSOs. We build upon their arguments and show that human capital, industry distance and parent size also influence the formation and performance of different types of spinouts. Importantly, our results provide a new explanation for past findings that WSOs perform better: WSOs perform better partly because individuals with higher human capital are more likely to form WSOs.

\section{Alternative explanations}

A. Individuals with high human capital learn more from large parents. Several studies have shown the benefits spinout founders receive from being at large parents (Agarwal et al., 2004; Chatterji, 2009). Individuals with high human capital may benefit more from the parent through learning, and hence, we may observe an increasing propensity to form spinouts (especially WSOs) with human capital. However, if this were the main driver of our results, we would expect individuals at larger parents to benefit from their parents and hence to be more likely to form spinouts. In our case, the effect of parent size is in the opposite direction. Further, the negative effect of parent size is stronger for WSOs than for OSOs, contrary to a knowledge-based explanation that would suggest that WSOs would benefit more.

B. Some types of individuals choose to work at small firms. Elfenbein et al. (2010) argue that some types of individuals may choose to work at small parents because (a) such firms may attract people with preferences common among those founders, (b) high ability in small firms translates to high ability in entrepreneurship, or (c) small firms provide skill development and an environment that 
is valuable for entrepreneurship. All of these explanations imply that individuals at small firms are more likely to form spinouts and thus explain the negative coefficient on parent size. In particular, we find the negative effect of parent size to be greatest for WSOs. For (a) to explain this finding, it must be that individuals with preferences associated with being a WSO founder sort disproportionately more into small parents than large parents. It is not clear why this would be true, since preferences for things such as autonomy and risk are unlikely to be correlated with distance from the parent industry. A similar argument suggests that (b) and (c) are unlikely to explain our results (e.g., the benefits for tighter pay for performance and entrepreneurial skills are likely to be similar for WSO and OSO founders). However, we cannot completely rule out a variant of (b) and (c). If high ability or learning in small firms were more relevant for the success of WSOs than OSOs, then we would observe a greater negative effect of parent size for WSOs. This appears less likely since larger firms are more likely to offer founders greater access to industry-specific knowledge and resources. Therefore, sorting alone does not seem to explain our results.

C. Distance is a proxy for the founder's misfit or unhappiness with industry. It has been argued that some individuals become entrepreneurs because of a lack of fit with their current job or because they lack abilities or attributes to succeed in the industry (Astebro et al., 2011; Dahl and Sorenson, 2014). This implies that misfits are more likely to form OSOs, and greater misfits are more likely to form OSO-Us. (Note that misfits with the parent but not the industry will not likely move outside the parent industry.) When a misfit occurs because the founder's skills do not match industry requirements, if the individual moves to a new industry where his or her skills are more applicable, there should be no performance penalty for OSOs relative to WSOs. However, this does not appear to be true; we find that WSOs tend to be significantly larger than OSOs. If the misfit is related to preferences, then individuals may be willing to sacrifice performance in order 
to be in an industry closer to their preference. This will explain the performance penalty for OSOs and the greater penalty for OSO-Us. However, it is not clear why the degree of such a misfit may vary systematically with human capital or even with parent size, which our results suggest. Therefore, misfit alone cannot explain the effect of industry distance.

\section{Implications for research}

Our study suggests that working at large parents may be a double-edged sword for potential spinout founders; although the founders can gain from the parents' knowledge and resources, they may also face a greater deterrent effect from such parents. Hence, future studies of spinout formation may benefit from extending the traditional view of parents as providers of pre-entry knowledge.

A second implication relates to the important effect of industry on new firm formation and performance. This study highlights the importance of the relation between the parent and destination industries and how that relation affects the formation (and performance) of spinouts. Further, if large parents dominate certain industries, spinout formation may be dissuaded in those industries. More studies to examine the policy implications (e.g., competition policy) of such situations may be insightful. Recent studies have begun to move beyond spinouts in parent industries, but our study suggests that deeper examinations of such spinouts may be fruitful. Finally, our study suggests a link between spinout formation and performance. Moving further in this direction and fully integrating formation and performance is likely to be valuable.

\section{References}

Abowd, J.M., Kramarz, F., \& Margolis, D.N. (1999). High wage workers and high wage firms. Econometrica, 67, 251-333.

Agarwal, R., Campbell, B.A., Franco, A.M., \& Ganco, M. (2016). What do I take with me? The mediating effect of spin-out team size and tenure on the founder-firm performance relationship. Academy of Management Journal, 59, 1060-1087.

Agarwal, R., Echambadi, R., Franco, A.M., \& Sarkar, M.B. (2004). Knowledge transfer through inheritance: spin-out generation, development, and survival. Academy of Management Journal, 47, 501-522.

Agarwal, R., \& Shah, S. (2014). Knowledge sources of entrepreneurship: Firm formation by 
academic, user and employee innovators. Research Policy, 43, 1109-1133.

Andersson, M., \& Klepper, S. (2013). Characteristics and performance of new firms and spinoffs in Sweden. Industrial and Corporate Change, 22, 245-280.

Anton, J.J., \& Yao, D.A. (1995). Start-ups, spin-offs, and internal projects. Journal of Law, Economics, and Organization, 11, 362-378.

Astebro, T., Chen, J., \& Thompson, P. (2011). Stars and misfits: self-employment and labor market frictions. Management Science, 57, 1999-2017.

Becker, G. (1964). Human Capital. Columbia University Press: New York.

Benedetto, G., Haltiwanger, J., Lane, J., \& McKinney, K.L. (2005). Using worker flows in the analysis of the firm. U.S. Census Bureau, LEHD Technical Paper No. TP-2003-09.

Brown, C., Haltiwanger, J., \& Lane, J. (2006). Economic Turbulence: The Impact on Workers, Firms and Inequality. University of Chicago Press: Chicago.

Campbell, B.A., Ganco, M,. Franco, A.M., \& Agarwal, R. (2012). Who leaves, where to, and why worry? employee mobility, entrepreneurship and effects on source firm performance. Strategic Management Journal, 33, 65-87.

Carnahan, S., Agarwal, R., \& Campbell, B.A. (2012). Heterogeneity in turnover: the effect of relative compensation dispersion of firms on the mobility and entrepreneurship of extreme performers. Strategic Management Journal, 33, 1411-1430.

Carnahan, S., Agarwal, R., Campbell, B.A, \& Choi, J. (2016). All in the tails? Pre-entry knowledge and the distribution of startup performance. Working Paper.

Carroll, G.R, Bigelow, L.S., Seidel, M.D.L., \& Tsai, L.B. (1996). The fates of de novo and de alio producers in the American automobile industry 1885-1981. Strategic Management Journal, 17, 117-137.

Cassiman, B., \& Ueda, M. (2006). Optimal project rejection and new firm start-ups. Management Science, 52, 262-275.

Chatterji, A.K. (2009). Spawned with a silver spoon? Entrepreneurial performance and innovation in the medical device industry. Strategic Management Journal, 30, 185-206.

Clarysse, B., Wright, M., \& Van de Velde, E. (2011). Entrepreneurial origin, technological knowledge, and the growth of spin-off companies. Journal of Management Studies, 48, 14201442.

Dahl, M.S., \& Sorenson, O. (2014). The who, why, and how of spinoffs. Industrial and Corporate Change, 23, 661-688.

Dustmann, C., \& Meghir C. (2005). Wages, experience and seniority. Review of Economic Studies, 72, 77-108.

Elfenbein, D.W., Hamilton, B.H., \& Zenger, T.R. (2010). The small firm effect and the entrepreneurial spawning of scientists and engineers. Management Science, 56, 659-681.

Eriksson, E., \& Kuhn, J.M. (2006). Firm spin-offs in Denmark 1981-2000: patterns of entry and exit. International Journal of Industrial Organization, 24, 1021-1040.

Franco, A.M., \& Filson, D. (2006). Spin-outs: knowledge diffusion through employee mobility. Rand Journal of Economics, 37, 841-860.

Ganco, M. (2013). Cutting the Gordian knot: the effect of knowledge complexity on employee mobility and entrepreneurship. Strategic Management Journal, 34, 666-686.

Ghemawat, P. (2001). Distance still matters. Harvard Business Review, 79(8), 137-147.

Golan, A., Lane, J., \& McEntarfer, E. (2007). The dynamics of worker reallocation within and across industries. Economica, 74, 1-20.

Gompers, P., Lerner, J., \& Scharfstein, D. (2005). Public corporations and the genesis of new 
ventures: 1986 to 1999. Journal of Finance, 60, 577-614.

Griliches, Z. (1979). Issues in assessing the contribution of research and development to productivity growth. Bell Journal of Economics, 10, 92-116.

Hamilton, B.H. (2000). Does entrepreneurship pay? An empirical analysis of the returns to self employment. Journal of Political Economy, 108, 604-631.

Helfat, C.E., \& Lieberman, M.B. (2002). The birth of capabilities: market entry and the importance of pre-history. Industrial and Corporate Change, 11, 725-760.

Hvide, H.K. (2009). The quality of entrepreneurs. Economic Journal, 119, 1010-1035.

Hyatt H, McEntarfer E. (2012). Job-to-job flows and the business cycle. CES Working Paper (CES 12-04).

Jarmin, R.S., Klimek, S.D., \& Miranda J. (2004). Firm entry and exit in the U.S. retail sector: 1977-1997. CES Working Paper (CES 04-17).

Kacperczyk, A., \& Marx, M. (2016). Revisiting the small-firm effect on entrepreneurship: Evidence from firm dissolutions. Organization Science, 27, 893-910.

Klepper, S. (2007). Disagreements, spinoffs, and the evolution of Detroit as the capital of the U.S. automobile industry. Management Science, 53, 616-631.

Klepper, S., \& Sleeper, S. (2005). Entry by spinoffs. Management Science, 51, 1291-1306.

Lazear, E.P. (2004). Balanced skills and entrepreneurship. American Economic Review, 94, 208211.

Neal, D. (1995). Industry-specific human capital: evidence from displaced workers. Journal of Labor Economics, 13, 653-677.

Nefke, F., Otto, A., \& Weyh, A. (2016). Inter-industry labor flows. Working Paper No. 72, Center for International Development, Harvard University.

Phillips, D.J. (2002). A genealogical approach to organizational life chances: the parent-progeny transfer among Silicon Valley law firms, 1946-1996. Administrative Science Quarterly, 47, 474506.

Poletaev, M., \& Robinson, C. (2008). Human capital specificity: Evidence from the dictionary of occupational titles and displaced worker surveys, 1984-2000. Journal of Labor Economics, 26, 387-420.

Poschke, M. (2013). Who becomes an entrepreneur? Labor market prospects and occupational choice. Journal of Economic Dynamics and Control, 37, 693-710.

Roach, M., \& Sauermann, H. (2015). Founder or joiner? The role of preferences and context in shaping different entrepreneurial interests. Management Science, 61, 2160-2184.

Rumelt, R.P. (1974). Strategy, Structure, and Economic Performance. Harvard University Press: Cambridge, MA.

Sapienza, H.J., Parhankangas, A., \& Autio, E. (2004). Knowledge relatedness and post-spin-off growth. Journal of Business Venturing, 19, 809-829.

Starr, E., Balasubramanian, N., \& Sakakibara, M. (2018). Screening spinouts? How noncompete enforceability affects the creation, growth, and survival of new firms. Management Science, 64, 552-572.

Walter, S.G., Heinrichs, S., Walter, A. (2014). Parent hostility and spin-out performance. Strategic Management Journal, 35, 2031-2042.

Watts, S. (2009). The people's tycoon: Henry Ford and the American century. Vintage Books. Zenger, T.R. (1992). Why do employers only reward extreme performance? Examining the relationships among performance, pay, and turnover. Administrative Science Quarterly, 37, 198219. 
Human capital, parent size and the destination industry of spinouts

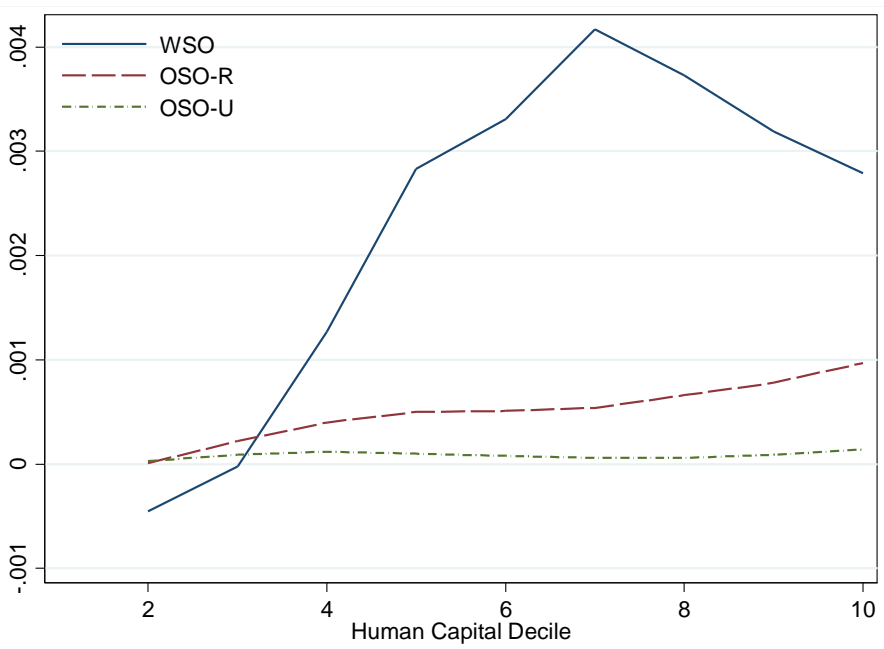

1a: Propensity to form spinouts
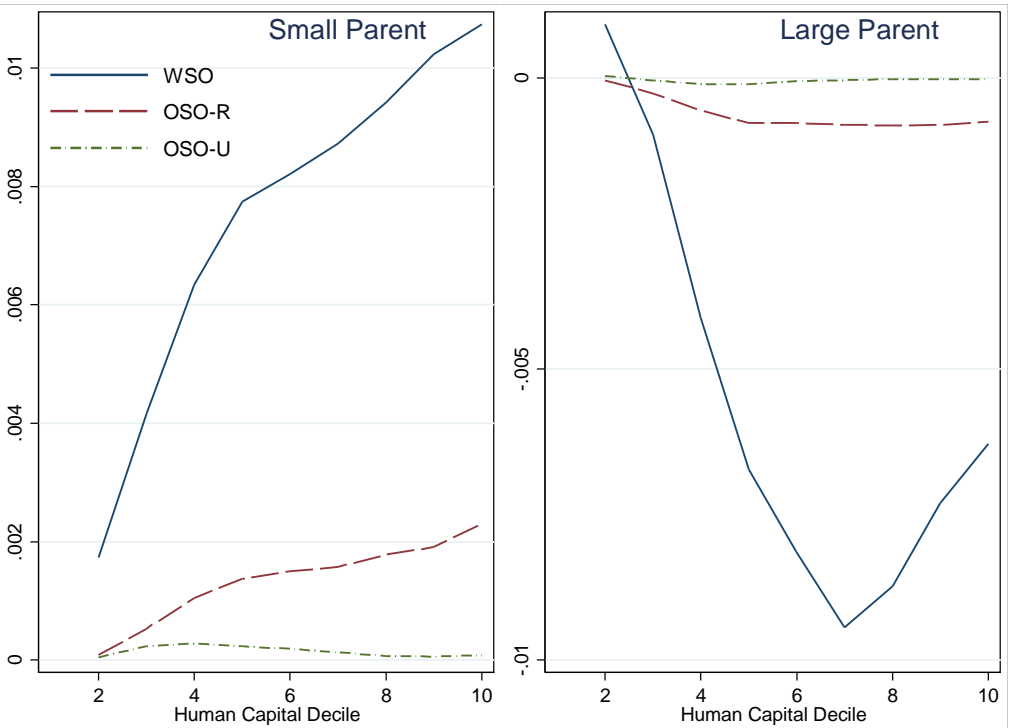

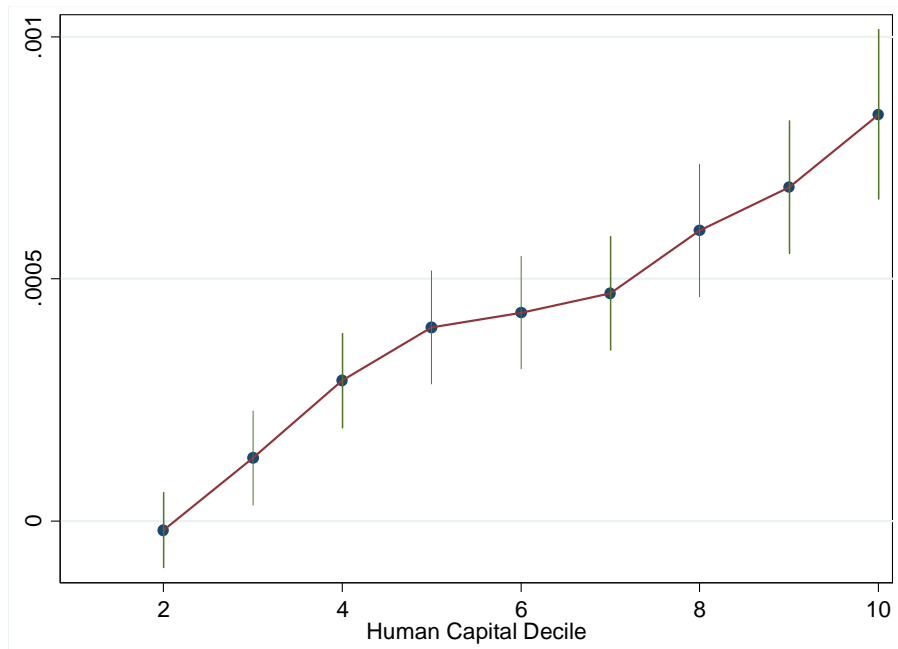

1b: Propensity to form OSO-R relative to OSO-U

Figure 1a plots Equation (1) coefficients on HC decile dummies for WSOs and total effects on HC decile dummies for OSO-R and OSO-U. Figure $1 b$ presents differences between the coefficients on HC decile dummies for OSO-R and OSO-U from Equation (1). Figure 1c presents estimated propensities to form spinouts by $\mathrm{HC}$ decile for two different parent sizes (0.5 s.d. below the mean, left, and 0.5 s.d. above the mean, right) from Equation (2).

1c: Parent size effect on propensity to form spinouts

Figure 1: Propensity to form spinouts and human capital 
Table 1. Sample summary statistics (weighted)

\begin{tabular}{|c|c|c|c|c|c|c|}
\hline \multirow[b]{2}{*}{ Variable } & \multicolumn{2}{|c|}{ Overall } & \multicolumn{2}{|c|}{ Founders } & \multicolumn{2}{|c|}{ Coworkers } \\
\hline & Mean & Std. dev & Mean & Std. dev & Mean & Std. dev \\
\hline Founder & 0.0015 & 0.0393 & 1 & 0 & 0 & 0 \\
\hline Log earnings & 8.1361 & 1.7124 & 8.4281 & 1.3269 & 8.1357 & 1.7129 \\
\hline Log parent size & 9.5649 & 1.5353 & 4.1298 & 2.3518 & 9.5733 & 1.5187 \\
\hline Log parent industry experience & 1.8890 & 1.1050 & 1.6199 & 0.9797 & 1.8894 & 1.1051 \\
\hline Log parent experience & 1.7176 & 1.1829 & 1.5609 & 1.0740 & 1.7179 & 1.1831 \\
\hline Log \# of industries worked & 0.9980 & 0.7971 & 0.8979 & 0.7155 & 0.9981 & 0.7972 \\
\hline Log spinout industry experience & 0.2880 & 0.9746 & 0.7115 & 1.0888 & 0.2874 & 0.9743 \\
\hline Log age & 4.9577 & 0.3650 & 4.9368 & 0.3611 & 4.9577 & 0.3650 \\
\hline Log education & 2.6403 & 0.3005 & 2.6214 & 0.2981 & 2.6403 & 0.3005 \\
\hline Unweighted N (Rounded) & \multicolumn{2}{|c|}{$4,220,000$} & \multicolumn{2}{|c|}{180,000} & \multicolumn{2}{|c|}{$4,040,000$} \\
\hline Corresponding weighted N & \multicolumn{2}{|c|}{$118,290,000$} & \multicolumn{2}{|c|}{180,000} & \multicolumn{2}{|c|}{$118,190,000$} \\
\hline $\begin{array}{l}\text { Avg. number of individuals at parent fi } \\
\text { represented by each individual in sample }\end{array}$ & \multicolumn{2}{|c|}{28.0} & \multicolumn{2}{|c|}{1.0} & \multicolumn{2}{|c|}{29.3} \\
\hline
\end{tabular}

a: For instance, the last column means that on average, each coworker in the sample represents 29.3 coworkers at the parent firm.

Table 2: Relative frequency of founders by human capital and spinout type

Panel A

\begin{tabular}{|c|c|c|c|c|c|c|c|c|c|c|c|}
\hline $\begin{array}{l}\text { Spinout type/ } \\
\text { HC decile }\end{array}$ & 1 & 2 & 3 & 4 & 5 & 6 & 7 & 8 & 9 & 10 & Total \\
\hline WSO & 3.29 & 7.39 & 10.03 & 11.97 & 13.09 & 13.02 & 12.88 & 11.42 & 8.66 & 8.25 & 100.00 \\
\hline OSO-R & 3.63 & 6.88 & 8.50 & 9.73 & 11.62 & 12.51 & 12.63 & 12.43 & 10.64 & 11.43 & 100.00 \\
\hline OSO-U & 6.83 & 11.23 & 12.15 & 11.89 & 11.78 & 11.34 & 10.64 & 9.51 & 7.59 & 7.04 & 100.00 \\
\hline Overall & 4.42 & 8.28 & 10.05 & 11.1 & 12.16 & 12.35 & 12.15 & 11.26 & 9.11 & 9.12 & 100.00 \\
\hline \multicolumn{12}{|l|}{ Panel B } \\
\hline $\begin{array}{l}\text { Spinout type/ } \\
\text { HC decile }\end{array}$ & 1 & 2 & 3 & 4 & 5 & 6 & 7 & 8 & 9 & 10 & Overall \\
\hline WSO & 25.04 & 30.06 & 33.61 & 36.34 & 36.25 & 35.50 & 35.70 & 34.14 & 32.02 & 30.48 & 33.68 \\
\hline OSO-R & 31.19 & 31.58 & 32.16 & 33.33 & 36.33 & 38.50 & 39.51 & 41.96 & 44.40 & 47.67 & 38.02 \\
\hline OSO-U & 43.77 & 38.36 & 34.23 & 30.33 & 27.42 & 26.00 & 24.80 & 23.90 & 23.59 & 21.85 & 28.31 \\
\hline Total & 100.00 & 100.00 & 100.00 & 100.00 & 100.00 & 100.00 & 100.00 & 100.00 & 100.00 & 100.00 & 100.00 \\
\hline
\end{tabular}

Panel A presents the relative frequency of founders by human capital for each type of spinout. Hence, the top cell in the first column indicates the proportion of all WSO founders in the first earnings decile. Panel B presents the relative frequency of each type of spinout by founder human capital decile. Hence, the top cell in the first column indicates the proportion of all founders in the first earnings decile who formed WSOs. 
Table 3. Propensity to form spinout by human capital level and spinout type

\begin{tabular}{|c|c|c|c|}
\hline & \multicolumn{3}{|c|}{ Type of spinout } \\
\hline & WSO & OSO-R & OSO-U \\
\hline Human capital decile 2 & $\begin{array}{l}-\mathbf{- 0 . 0 0 0 4 5} \\
(0.00013)\end{array}$ & $\begin{array}{l}\mathbf{0 . 0 0 0 4 6} \\
(0.00014)\end{array}$ & $\begin{array}{l}\mathbf{0 . 0 0 0 4 8} \\
(0.00013)\end{array}$ \\
\hline Human capital decile 3 & $\begin{array}{l}-0.00002 \\
(0.00015)\end{array}$ & $\begin{array}{l}0.00024 \\
(0.00015)\end{array}$ & $\begin{array}{l}0.00011 \\
(0.00015)\end{array}$ \\
\hline Human capital decile 4 & $\begin{array}{l}\mathbf{0 . 0 0 1 2 7} \\
(0.00032)\end{array}$ & $\begin{array}{l}-\mathbf{0 . 0 0 0 8 7} \\
(0.00030)\end{array}$ & $\begin{array}{l}-\mathbf{0 . 0 0 1 1 5} \\
(0.00032)\end{array}$ \\
\hline Human capital decile 5 & $\begin{array}{l}\mathbf{0 . 0 0 2 8 3} \\
(0.00056)\end{array}$ & $\begin{array}{l}-\mathbf{0 . 0 0 2 3 3} \\
(0.00054)\end{array}$ & $\begin{array}{l}-\mathbf{0 . 0 0 2 7 3} \\
(0.00056)\end{array}$ \\
\hline Human capital decile 6 & $\begin{array}{l}\mathbf{0 . 0 0 3 3 1} \\
(0.00065)\end{array}$ & $\begin{array}{c}-\mathbf{0 . 0 0 2 8 0} \\
(0.00064)\end{array}$ & $\begin{array}{r}-\mathbf{0 . 0 0 3 2 3} \\
(0.00066)\end{array}$ \\
\hline Human capital decile 7 & $\begin{array}{l}\mathbf{0 . 0 0 4 1 7} \\
(0.00070)\end{array}$ & $\begin{array}{l}-\mathbf{0 . 0 0 3 6 3} \\
(0.00068)\end{array}$ & $\begin{array}{l}-\mathbf{0 . 0 0 4 1 1} \\
(0.00070)\end{array}$ \\
\hline Human capital decile 8 & $\begin{array}{l}\mathbf{0 . 0 0 3 7 3} \\
(0.00068)\end{array}$ & $\begin{array}{l}-\mathbf{0 . 0 0 3 0 7} \\
(0.00066)\end{array}$ & $\begin{array}{l}-\mathbf{0 . 0 0 3 6 7} \\
(0.00069)\end{array}$ \\
\hline Human capital decile 9 & $\begin{array}{l}\mathbf{0 . 0 0 3 1 9} \\
(0.00064)\end{array}$ & $\begin{array}{l}-\mathbf{0 . 0 0 2 4 1} \\
(0.00062)\end{array}$ & $\begin{array}{c}-\mathbf{0 . 0 0 3 1 0} \\
(0.00064)\end{array}$ \\
\hline Human capital decile 10 & $\begin{array}{l}\mathbf{0 . 0 0 2 7 9} \\
(0.00056)\end{array}$ & $\begin{array}{c}-\mathbf{0 . 0 0 1 8 2} \\
(0.00053)\end{array}$ & $\begin{array}{l}-\mathbf{0 . 0 0 2 6 5} \\
(0.00056)\end{array}$ \\
\hline Log parent industry experience & $\begin{array}{l}\mathbf{0 . 0 2 2 5 9} \\
(0.00225)\end{array}$ & $\begin{array}{l}-\mathbf{0 . 0 2 2 7 4} \\
(0.00225)\end{array}$ & $\begin{array}{l}-\mathbf{0 . 0 2 2 8 1} \\
(0.00225)\end{array}$ \\
\hline Log parent experience & $\begin{array}{l}\mathbf{0 . 0 0 0 2 6} \\
(0.00009)\end{array}$ & $\begin{array}{l}-0.00003 \\
(0.00009)\end{array}$ & $\begin{array}{l}-0.00007 \\
(0.00009)\end{array}$ \\
\hline Log \# of industries worked & $\begin{array}{l}-\mathbf{0 . 0 0 0 3 7} \\
(0.00008)\end{array}$ & $\begin{array}{l}\mathbf{0 . 0 0 1 2 8} \\
(0.00009)\end{array}$ & $\begin{array}{l}\mathbf{0 . 0 0 0 7 5} \\
(0.00008)\end{array}$ \\
\hline Log spinout industry experience & $\begin{array}{c}-\mathbf{0 . 0 2 3 7 8} \\
(0.00235)\end{array}$ & $\begin{array}{l}\mathbf{0 . 0 2 3 6 0} \\
(0.00233)\end{array}$ & $\begin{array}{l}\mathbf{0 . 0 2 4 5 4} \\
(0.00235)\end{array}$ \\
\hline Log age & $\begin{array}{l}0.00017 \\
(0.00016)\end{array}$ & $\begin{array}{l}-0.00014 \\
(0.00016)\end{array}$ & $\begin{array}{l}-0.00022 \\
(0.00016)\end{array}$ \\
\hline Log education & $\begin{array}{l}\mathbf{0 . 0 0 0 3 0} \\
(0.00012)\end{array}$ & $\begin{array}{l}-0.00016 \\
(0.00012)\end{array}$ & $\begin{array}{l}-0.00027 \\
(0.00012)\end{array}$ \\
\hline $\begin{array}{l}\# \text { of observations } \\
R^{2} \\
\text { Parent-vear-quarter fix }\end{array}$ & & $\begin{array}{c}4,220,00 \\
0.175 \\
\text { Yes }\end{array}$ & \\
\hline
\end{tabular}

This table shows the results from one regression that estimates Equation (1). Standard errors clustered by parent in parentheses. The sample consists of spinout founders and their coworkers. Dependent variable: 1 if an individual is a founder, 0 otherwise. WSO and human capital decile 1 are omitted categories. The WSO column shows the coefficients on the variables in the first column, and the OSO-R and OSO-U columns show the coefficients on the interactions of those variables with each type of spinout. This regression was run with sampling weights to adjust for coworker sampling. The number of observations is rounded to the nearest 10,000. Coefficients with $p$-values less than 0.01 are in bold. Coefficients on gender and alien status are not presented due to disclosure concerns. 
Table 4. Propensity to form spinout by human capital level and spinout type: Role of parent size

\begin{tabular}{|c|c|c|c|}
\hline & \multicolumn{3}{|c|}{ Type of spinout } \\
\hline & WSO & OSO-R & OSO-U \\
\hline Human capital decile 2 & $\begin{array}{l}0.00640 \\
(0.00591)\end{array}$ & $\begin{array}{l}-0.00561 \\
(0.00566)\end{array}$ & $\begin{array}{l}-0.00626 \\
(0.00591)\end{array}$ \\
\hline Human capital decile 3 & $\begin{array}{l}\mathbf{0 . 0 3 3 6 4} \\
(0.00894)\end{array}$ & $\begin{array}{c}-\mathbf{0 . 0 2 8 5 3} \\
(0.00847)\end{array}$ & $\begin{array}{l}-\mathbf{0 . 0 3 1 8 2} \\
(0.00894)\end{array}$ \\
\hline Human capital decile 4 & $\begin{array}{l}\mathbf{0 . 0 6 6 2 5} \\
(0.01203)\end{array}$ & $\begin{array}{c}\mathbf{- 0 . 0 5 5 9 6} \\
(0.01147)\end{array}$ & $\begin{array}{c}\mathbf{- 0 . 0 6 3 7 7} \\
(0.01203)\end{array}$ \\
\hline Human capital decile 5 & $\begin{array}{l}\mathbf{0 . 0 9 0 6 1} \\
(0.01434)\end{array}$ & $\begin{array}{l}-\mathbf{0 . 0 7 6 9 2} \\
(0.01373)\end{array}$ & $\begin{array}{l}-\mathbf{0 . 0 8 8 4 4} \\
(0.01433)\end{array}$ \\
\hline Human capital decile 6 & $\begin{array}{l}\mathbf{0 . 1 0 1 9} \\
(0.01548)\end{array}$ & $\begin{array}{c}-\mathbf{0 . 0 8 7 3 8} \\
(0.01487)\end{array}$ & $\begin{array}{l}-\mathbf{0 . 1 0 0 3} \\
(0.01548)\end{array}$ \\
\hline Human capital decile 7 & $\begin{array}{l}\mathbf{0 . 1 1 2 8} \\
(0.01636)\end{array}$ & $\begin{array}{l}-\mathbf{0 . 0 9 7 5 9} \\
(0.01570)\end{array}$ & $\begin{array}{l}-\mathbf{0 . 1 1 1 7} \\
(0.01635)\end{array}$ \\
\hline Human capital decile 8 & $\begin{array}{l}\mathbf{0 . 1 1 3 4} \\
(0.01656)\end{array}$ & $\begin{array}{l}-\mathbf{0 . 0 9 6 7 5} \\
(0.01586)\end{array}$ & $\begin{array}{l}-\mathbf{0 . 1 1 2 8} \\
(0.01655)\end{array}$ \\
\hline Human capital decile 9 & $\begin{array}{l}\mathbf{0 . 1 1 0 7} \\
(0.01724)\end{array}$ & $\begin{array}{c}-\mathbf{0 . 0 9 3 2 2} \\
(0.01650)\end{array}$ & $\begin{array}{l}-\mathbf{0 . 1 1 0 2} \\
(0.01724)\end{array}$ \\
\hline Human capital decile 10 & $\begin{array}{l}\mathbf{0 . 1 0 8 3} \\
(0.01891)\end{array}$ & $\begin{array}{l}-\mathbf{0 . 0 8 8 4 9} \\
(0.01803)\end{array}$ & $\begin{array}{l}-\mathbf{0 . 1 0 7 6} \\
(0.01890)\end{array}$ \\
\hline Log parent employment $\times$ HC decile 2 & $\begin{array}{l}-0.00053 \\
(0.00060)\end{array}$ & $\begin{array}{l}0.00045 \\
(0.00057)\end{array}$ & $\begin{array}{l}0.00052 \\
(0.00060)\end{array}$ \\
\hline Log parent employment $\times$ HC decile 3 & $\begin{array}{c}-\mathbf{0 . 0 0 3 3 5} \\
(0.00095)\end{array}$ & $\begin{array}{l}\mathbf{0 . 0 0 2 8 3} \\
(0.00089)\end{array}$ & $\begin{array}{l}\mathbf{0 . 0 0 3 1 7} \\
(0.00095)\end{array}$ \\
\hline Log parent employment $\times$ HC decile 4 & $\begin{array}{l}-\mathbf{0 . 0 0 6 8 1} \\
(0.00135)\end{array}$ & $\begin{array}{l}\mathbf{0 . 0 0 5 7 6} \\
(0.00128)\end{array}$ & $\begin{array}{l}\mathbf{0 . 0 0 6 5 6} \\
(0.00134)\end{array}$ \\
\hline Log parent employment $\times$ HC decile 5 & $\begin{array}{c}-\mathbf{0 . 0 0 9 4 2} \\
(0.00167)\end{array}$ & $\begin{array}{l}\mathbf{0 . 0 0 8 0 2} \\
(0.00159)\end{array}$ & $\begin{array}{l}\mathbf{0 . 0 0 9 2 0} \\
(0.00167)\end{array}$ \\
\hline Log parent employment $\times$ HC decile 6 & $\begin{array}{r}-\mathbf{0 . 0 1 0 6 5} \\
(0.00183)\end{array}$ & $\begin{array}{l}\mathbf{0 . 0 0 9 1 7} \\
(0.00175)\end{array}$ & $\begin{array}{l}\mathbf{0 . 0 1 0 4 9} \\
(0.00182)\end{array}$ \\
\hline Log parent employment $\times$ HC decile 7 & $\begin{array}{r}-\mathbf{0 . 0 1 1 8 3} \\
(0.00195)\end{array}$ & $\begin{array}{l}\mathbf{0 . 0 1 0 2 8} \\
(0.00186)\end{array}$ & $\begin{array}{l}\mathbf{0 . 0 1 1 7 2} \\
(0.00194)\end{array}$ \\
\hline Log parent employment $\times$ HC decile 8 & $\begin{array}{c}-\mathbf{0 . 0 1 1 8 2} \\
(0.00194)\end{array}$ & $\begin{array}{l}\mathbf{0 . 0 1 0 1 3} \\
(0.00185)\end{array}$ & $\begin{array}{l}\mathbf{0 . 0 1 1 7 6} \\
(0.00194)\end{array}$ \\
\hline Log parent employment $\times$ HC decile 9 & $\begin{array}{l}-\mathbf{0 . 0 1 1 4 2} \\
(0.00202)\end{array}$ & $\begin{array}{l}\mathbf{0 . 0 0 9 6 5} \\
(0.00192)\end{array}$ & $\begin{array}{l}\mathbf{0 . 0 1 1 3 7} \\
(0.00201)\end{array}$ \\
\hline Log parent employment $\times$ HC decile 10 & $\begin{array}{l}-\mathbf{0 . 0 1 1 0 9} \\
(0.00219)\end{array}$ & $\begin{array}{l}\mathbf{0 . 0 0 9 1 0} \\
(0.00208)\end{array}$ & $\begin{array}{l}\mathbf{0 . 0 1 1 0 2} \\
(0.00219)\end{array}$ \\
\hline \# of observations & & $4,220,00$ & \\
\hline$R^{2}$ & & $\begin{array}{c}0.177 \\
\text { Yes }\end{array}$ & \\
\hline
\end{tabular}

This table shows the results from one regression that estimates Equation (2). Coefficients on control variables not presented to conserve space and are available on request. Standard errors clustered by parent in parentheses. Refer to notes under Table 3 for further details. 
Table 5. Analysis of spinout performance

\begin{tabular}{|c|c|c|c|c|c|c|}
\hline & \multicolumn{3}{|c|}{ Age 0} & \multicolumn{3}{|c|}{ Age 3} \\
\hline & $(1)$ & $(2)$ & (3) & (4) & (5) & (6) \\
\hline OSO-R dummy & $\begin{array}{l}-\mathbf{0 . 3 1 1 0} \\
(0.00956)\end{array}$ & $\begin{array}{l}-0.09213 \\
(0.1069)\end{array}$ & $\begin{array}{l}\mathbf{1 . 0 5 9 1} \\
(0.1063)\end{array}$ & $\begin{array}{c}-\mathbf{0 . 2 0 5 2} \\
(0.0137)\end{array}$ & $\begin{array}{c}-0.1493 \\
(0.1258)\end{array}$ & $\begin{array}{l}\mathbf{1 . 2 0 6 6} \\
(0.1561)\end{array}$ \\
\hline OSO-U dummy & $\begin{array}{l}-\mathbf{0 . 4 8 1 3} \\
(0.00929)\end{array}$ & $\begin{array}{l}0.1344 \\
(0.1105)\end{array}$ & $\begin{array}{l}\mathbf{1 . 4 8 2 5} \\
(0.1010)\end{array}$ & $\begin{array}{l}-\mathbf{0 . 3 9 4 9} \\
(0.01350)\end{array}$ & $\begin{array}{l}0.09538 \\
(0.1316)\end{array}$ & $\begin{array}{l}1.4923 \\
(0.1507)\end{array}$ \\
\hline Founder HC & & $\begin{array}{l}\mathbf{0 . 1 7 1 8} \\
(0.0136)\end{array}$ & $\begin{array}{l}\mathbf{0 . 3 5 2 7} \\
(0.01036)\end{array}$ & & $\begin{array}{l}\mathbf{0 . 1 5 2 8} \\
(0.01538)\end{array}$ & $\begin{array}{l}\mathbf{0 . 3 3 8 6} \\
(0.01442)\end{array}$ \\
\hline OSO-R × Founder HC & & $\begin{array}{c}-0.01938 \\
(0.01295)\end{array}$ & $\begin{array}{l}-\mathbf{0 . 1 3 7 3} \\
(0.01257)\end{array}$ & & $\begin{array}{l}-0.00095 \\
(0.01500)\end{array}$ & $\begin{array}{l}-\mathbf{0 . 1 4 0 0} \\
(0.01798)\end{array}$ \\
\hline OSO-U × Founder HC & & $\begin{array}{c}-\mathbf{0 . 0 5 9 8 2} \\
(0.01337)\end{array}$ & $\begin{array}{l}-\mathbf{0 . 1 9 8 9} \\
(0.01213)\end{array}$ & & $\begin{array}{l}-\mathbf{0 . 0 4 5 1 9} \\
(0.01580)\end{array}$ & $\begin{array}{l}-\mathbf{0 . 1 8 2 8} \\
(0.01792)\end{array}$ \\
\hline Parent size & & & $\begin{array}{l}\mathbf{0 . 4 5 2 5} \\
(0.02064)\end{array}$ & & & $\begin{array}{l}\mathbf{0 . 5 0 9 6} \\
(0.02916)\end{array}$ \\
\hline OSO-R $\times$ Parent size & & & $\begin{array}{l}-\mathbf{0 . 3 3 9 8} \\
(0.02370)\end{array}$ & & & $\begin{array}{l}-\mathbf{0 . 4 1 0 0} \\
(0.03447)\end{array}$ \\
\hline OSO-U × Parent size & & & $\begin{array}{l}-\mathbf{0 . 3 8 5 9} \\
(0.02270)\end{array}$ & & & $\begin{array}{l}-\mathbf{0 . 4 2 7 9} \\
(0.03309)\end{array}$ \\
\hline Founder HC $\times$ Parent size & & & $\begin{array}{c}\mathbf{- 0 . 0 4 6 3 0} \\
(0.00221)\end{array}$ & & & $\begin{array}{r}\mathbf{- 0 . 0 4 9 9 9} \\
(0.00303)\end{array}$ \\
\hline Founder $\mathrm{HC} \times$ OSO $-\mathrm{R} \times$ Parent size & & & $\begin{array}{l}\mathbf{0 . 0 3 3 0 1} \\
(0.00259)\end{array}$ & & & $\begin{array}{l}\mathbf{0 . 0 3 9 7 6} \\
(0.00361)\end{array}$ \\
\hline Founder $\mathrm{HC} \times$ OSO$-\mathrm{U} \times$ Parent size & & & $\begin{array}{l}\mathbf{0 . 0 3 8 0 8} \\
(0.00249) \\
\end{array}$ & & & $\begin{array}{l}\mathbf{0 . 0 4 0 3 8} \\
(0.00359) \\
\end{array}$ \\
\hline $\mathrm{N}$ & 83,000 & 83,000 & 83,000 & 48,000 & 48,000 & 48,000 \\
\hline$R^{2}$ & 0.136 & 0.183 & 0.192 & 0.156 & 0.187 & 0.196 \\
\hline
\end{tabular}

Industry-year fixed effects included in all specifications. Standard errors clustered by parent in parentheses. Coefficients with p-values less than 0.01 are in bold. 